\title{
Rangeland Recovery Potential: Soil Seed Content and Seed Viability
}

\author{
JACK L. Butler $\uparrow$ Kara J. PAintNer \\ DEPARTMENT OF BIOLOGY $\downarrow$ UNIVERSITY OF SOUTH DAKOTA \\ VERMILLION
}

In most plant communities, soil contains a seed bank (population of dormant seeds), (Harper 1977), which provides a partial record of past and present vegetation (Major and Pyott 1966, Johnson and Anderson 1986). Seed banks are continuously rejuvenated by a "seed rain", from vegetation located on- and off-site. If existing communities are disturbed or destroyed, the seed bank provides a potential source of propagules during succession (Egler 1954, Connell and Slatyer 1977). Consequently, seed banks may serve as an index in predicting what vegetation changes might occur if environmental conditions are favorable for germination (Harper 1977). The objectives of this study are to

1. evaluate the viable seed bank within grazed and relict pinyon-juniper and blackbrush/ Indian ricegrass communities in Glen Canyon National Recreation Area (GCNRA),

2. assess the ability of these communities to recover following a disturbance, using their respective seed banks as indicators of recovery potential, and

3. address the suitability of using seed banks to monitor and predict community level composition changes in response to various intensities of grazing.

This study is being integrated with a multi-year, site-characterization project in GCNRA, that is currently funded by the UW-NPS Research Center.
The objectives of that project are to

1. identify and evaluate the abiotic and biotic factors influencing structure and species composition of relict and grazed pinyonjuniper and blackbrush/Indian ricegrass communities, and

2. to select, refine and validate a system that can be used to field monitor condition and trend of grazed and relict communities within the GCNRA.

The integration of both projects should provide valuable insight to natural resource managers in the design, implementation and evaluation of specific land-use plans.

Sampling of the seed bank within grazed and relict pinyon-juniper and blackbrush/Indian ricegrass communities began in mid-May, 1990 and was conducted in conjunction with the multi-year project described above. Selection of specific study sites for the proposed seed bank study was based on the procedures outlined for the multi-year project (Butler, Bich, Schmidt 1990.

A reconnaissance of blackbrush/ricegrass and pinyon-juniper relict areas was conducted during the first few days of the 1990 field season. The purpose of that survey was to characterize each relict community with respect to soil depth, texture, site aspect and slope steepness. Since the botanical composition and productivity of a plant community are influenced by 
the various interactions of weather, grazing, soils and topography, it is important to separate the effects of the physical environment of the site from the effects of grazing. It is assumed that grazed areas that have physical characteristics similar to the relict areas have the potential to produce a similar plant community, even though current botanical composition and productivity may have been modified by grazing (Shiflett 1973).

Once the physical criteria for selection of study sites were established, a survey was conducted to locate grazed areas that best represented the end product of three grazing regimes (light, moderate, and heavy). Distance from water and the extent of physical evidence of livestock (degree of soil disturbance, number and extent of trails, presence of feces) were the criteria that were used to classify a site as either being lightly, moderately or heavily grazed by cattle.

Soil seed bank data were collected from a 50 X 50 $\mathrm{m}$ plot randomly located within each of the selected grazed and ungrazed pinyon-juniper and blackbrush/ ricegrass communities. Because of the possible interactions between seed reserves, perennial vegetation and granivorous rodent populations, collection of soil samples for analysis of seed reserves were stratified according to the vegetation matrix of the pinyon-juniper community (Nelson and Chew 1977). Samples were collected from under the canopies of the dominant trees (UC=under canopy) and from the exposed interstitial spaces between plants (EX=exposed).

Ten random soil samples were collected from under the canopy of the nearest "suitable" tree for each of the major species (Pinus edulis and Juniperus osteosperma), and from the center of the exposed area nearest to the sampling point. "Suitable" was defined as the tree that was not less than the average size for that species. Average size was subjectively determined. Samples of UC were collected from an area mid-way between the stem of the individual and the edge of the canopy. Consequently, ten soil samples were collected from EX and 20 from UC (10 for $P$. edulis, 10 for J. osteosperma) for each grazing regime. Because of the difficulty in identifying a relict and/or lightly grazed pinyon-juniper community, soil samples were only taken from subjectively determined moderately and heavily grazed sites. For the blackbrush/Indian ricegrass communities, twenty-five randomly located soil samples were taken from exposed areas within each grazed and relict community ( 4 grazing regimes $X 25$ samples $=100$ soil samples for the blackbrushUndian ricegrass community type).

At each randomly selected soil sampling point, a $20 \times 50 \mathrm{~cm}$ frame was placed and all of the soil within the frame to a depth of $3 \mathrm{~cm}$ was collected, placed in a paper sack, air dried and stored at room temperature. The majority of the seeds are generally concentrated in the top $3 \mathrm{~cm}$ of soil (Koniak and Everett 1982).

Samples were collected from mid-May to late-June of 1990. The samples were sieved through a $2 \mathrm{~mm}$ screen and any remaining non-vegetative material was discarded. Any propagules too large to pass through the screen were identified and collected. The soil was thoroughly mixed and divided into approximately two equal portions. One portion was used immediately in germination tests conducted in an outside greenhouse. The remaining portion was stored in a plastic bag and maintained for 10 weeks at $1-3^{\circ} \mathrm{C}$.

The soil samples were uniformly spread to a depth of $1 \mathrm{~cm}$ on top of $2 \mathrm{~cm}$ of a sterile vermiculite-peat moss mixture in a standard seeding flat. Flats were randomized on a greenhouse bench and will be watered as needed. The greenhouse is being maintained at approximately ambient environmental conditions with a $12 \mathrm{~h}$ photoperiod. Seedlings will be identified and removed as they emerge. Unidentifiable seedlings will be grown to maturity and collected for identification. After 10 weeks, the samples that were placed in cold storage will be removed and returned to the greenhouse for germination tests as described above.

Standard analysis of variance procedures will be used to evaluate differences in seed bank composition and density among grazing treatments within each community type. Means will be separated using Duncan's multiple range test. Composition of the seed bank will be compared to extant vegetation (as sampled by the multi-year, site-characterization study described previously).

\section{Literature Cited}

Butler, J. L., B. S. Bich, and C. A. Schmidt. 1990. Characterization of relict communities for monitoring park ecosystems in Glen Canyon National Recreation Area. UW-NPS Research Center Annual Report, University of Wyoming, Laramie. 
Connell, J.H., and R.O. Slatyer. 1977. Mechanisms of succession in natural communities and their role in community stability and organization. Am. Nat. 111:1119-1144.

Egler, F.E. 1954. Vegetation science concepts I. Initial floristic composition, a factor in old field vegetation development. Vegetatio 4:412-417.

Harper, J.L. 1977. Population Biology of Plants. Academic Press Inc., New York, New York, USA.

Johnson, R.G., and R.C. Anderson. 1986. The seed bank of a tallgrass prairie in Illinois. Am. Midl. Nat. 115:123-130.

Koniak, S., and R.L. Everett. 1982. Seed reserves in soils of successional stages of pinyon woodlands. Am. Midl. Nat. 108:295-303.
Major, J., and W.T. Pyott. 1966. Buried viable seeds in two California bunchgrass sites and their bearing on the definition of a flora. Vegetatio 13:253-282.

Nelson, J.F., and R.M. Chew. 1977. Factors affecting seed reserves in the soil of a Mojave Desert ecosystem, Rock Valley, Nye County, Nevada. Am. Midl. Nat. 97:300-320. 